821.163.41.09“20“

https://doi.org/10.18485/mks_srpska_slavistika.2018.2.ch9

\author{
Владислава С. ГОРДИЋ ПЕТКОВИЋ* \\ Универзитет у Новом Саду \\ Филозофски факултет \\ Одсек за англистику
}

\title{
РЕЛЕВАНТНОСТ РОДНОГ ИСКУСТВА У САВРЕМЕНОЈ СРПСКОЈ ПРОЗИ
}

\begin{abstract}
На примеру романа неколико српских прозаисткиња, Јелене Ленголд, Славице Гароње, Љубице Мркаљ и Тање Ступар Трифуновић, између осталих - ауторки запажених остварења, награђиваних и превођених на словенске језике - позабавићемо се релевантношћу женског искуства, чија се литерарна обрада темељи на амбивалентном односу према уметничкој традицији и стваралачкој пракси. Праћена страхом да ће се уникатност доживљеног прометнути у клише, свака ауторка се пита да ли је искуство женског одрастања (често сврставаног у теме које нису припадале великим нарацијама, нити им је признавана социоисторијска релевантност) довољно значајан потенцијал инспирације. Аутобиографска књига прозе Љубице Мркаљ Испричавалице и роман Повратак у Аркадију Славице Гароње откривају важност рекапитулације детињства за формирање слике о себи и свету, док се Тања Ступар Трифуновић у роману Сатови у мајчиној соби бави кризама женске зрелости, надовезујући се на дела која негују интимистички и исповедни поступак као оквир за мудру и вишезначну игру значењем и структурама, успостављајући кореспонденције са романом Пада Авала Биљане Јовановић и Балтимор Јелене Ленголд.

Кључне речи: роман, одрастање, женско искуство, поетика, доживљено, аутофикција.
\end{abstract}

Проучавање женског доприноса историји, политици, уметности и култури почиње од признавања специфичности женског искуства као родног искуства, или би барем тако требало да буде: но, тај је први корак истовремено било најтеже начинити. Већ је Џон Стјуарт Мил (John Stuart Mill) појам женске природе сматрао ограничењем и вештачком идејом, резултатом принудних ограничења и неприродних подстицаја (Mill 1995). Од 1869. године, у којој настаје његов есеј „Потчињеност жена" па до успостављања тезе о родном идентитету у студији Роберта Столера Пол и род (Stoller 1968) био је потребан безмало цео век да би се артикулисала идеја о роду као скупу одлика које су усвојене и стечене, социолошки и културолошки мотивисане, и да би се до краја оспорио биолошки детерминизам, који улоге муш-

*vladislava.gordic.petkovic@ff.uns.ac.rs 
караца и жена види као предодређене и непомериве. Доказ колико је сложен процес истраживања родних представа и родних искустава свакако је и гинокритика, чије се релативно касно појављивање на књижевнотеоријској сцени може објаснити једино чињеницом да је, да би се креирао засебан женски оквир за проучавање женских текстова од околности њиховог настанка па до њихове анализе и интерпретације, било потребно дуго савладавати многе отпоре.

Реализам има много протејских лица, а у женском ауторству зна да се огласи испод мноштва различитих маски, у неочекиваним и нелогичним контекстима, у игри жанровских одлика и културних стереотипа, у сучељавању свих оних подстицаја и ограничења која је Мил помињао. Донекле због непостојања предуслова за уметничко стварање али добрим делом и због прећутно подржаване андроцентричности у свим сферама деловања, женско искуство вековима је измештано у простор тема које нису припадале великим нарацијама нити им је признавана социоисторијска релевантност. Ипак, женско ауторство се афирмисало на јединственом противречју жеље за лоцирањем у традицији која женскост не чини довољно видљивом, и за истовременим порицањем веза са канонском књижевношћу. Књижевност женских тема разрешава противречну потребу истовременог сврставања и порицања припадности: јунакиња је обично део света који или постепено упознаје, или се од њега удаљава, те је тако проблем остваривања контакта и обликовања идентитета увек актуелан у књижевности коју пишу ауторке. Не осећа се припадност породици и заједници као доказ сигурности и заштићености јер та припадност онемогућава све ризике потраге за зрелошћу и самосвојношћу, и представу о животу као палимпсесту у ком се један преко другог исписују искуства, идентитети и саобраћања. Потреба да се женско искуство синтетизује, предочи као релевантно за прочишћење и освешћење види се већ у самој чињеници да прозу, односно роман, пишу и ауторке које нису прозаисткиње по свом примарном опредељењу. Књижевну прозу пише и теоретичарка Светлана Слапшак, која у роману Равнотежа деконструише жанрове и поетике, но исто тако и клишее и стереотипне представе о жени, настављајући сатиричну и игриву нит раних романа Дубравке Угрешић, док Мирјана Ђурђевић (придошлица у романескни свет из техничко-технолошког научног поља) у сатиричном приступу детективском жанру и популарној књижевности истовремено описује и критикује искуства женског психофизичког сазревања и социјалне интеграције. Песникиња Нина Живанчевић у низу прозних дела са елементима аутофикције дефинише и артикулише потрагу за језиком, телом и сећањем, а у овом раду ћемо се задржати на романима који настају из пера књижевних теоретичарки, сликарки и песникиња. Писани у форми реминисценције или евокације искуства, романи неколико српских списатељица откривају да одрастање и сазревање жене може да буде тема која ће послужити да се илуструје различитост, особеност и формативне кризе, најчешће у аморфној и флуидној форми која одбија да буде јасно дефинисана. Сећање може бити и идилично и трауматично, али помаже да се артикулише исказ о формативним утицајима.

У роману Повратак у Аркадију Славица Гароња описује детињство, користећи митски потенцијал појма Аркадија као упечатљиву метафору завичаја и специфичног душевног стања. Епиграф романа је цитат из научног рада „Мотив Аркадије у дечјој књижевности" Тијане Тропин, у ком се истиче повезаност појма Аркадије са 
детињством човека и златним добом човечанства, и наглашава: „Да би настала Аркадија, потребно је да друштво коме песник припада досегне степен урбанизације када је раздаљина до ратарског и пастирског живота довољно велика да ови почну да делују примамљиво, пријатно и једноставно у односу на градски живот” (Тропин y: Гароња 2014: sine pagina). У предговору дефинисан као „биографска исповест и породично-завичајна хроника" (Гароња 2014: XI) са елементима анегдоте, репортаже и есеја, роман је великим делом интимни путопис о одрастању у једном јасно дефинисаном простору, о сазревању и формирању личности заснованом не само на аутобиографском искуству, него и на колективном памћењу, на упијању традиције. Следећи идеју о матрилинеарности као заметнутој традицији и наслеђеном наративу, приповедачица идилично детињство призива кроз поновни сусрет са западном Славонијом који се догоди када своју кћер доведе у родни крај, са жељом да мајка и тетка које се нису виделе пуних седамнаест година обнове контакт. Повратак у Аpкадију указује на расцеп између две равни у времену и простору, подсећајући да је реконструкција идиле и из чисто текстуалних разлога неодржива, премда ће сањана димензија прохујалог времена увек остати надохват руке. Низ опозиција, рурално-урбано, прошлост-садашњост, идила-реалност допуњен је супротстављањем књижевног текста и критичког дискурса, које је неминовно већ и самом чињеницом да се свако сећање просејава и прерађује. Роман је замишљен као мозаик реминисценција ослоњен на приче изроњене из породичних фотографија које раскривају пределе и људе, простор на коме живе вредни и срчани сељаци, који су се борили са оскудицом, тегобним животом, на издашном тлу које је опустело, у приповеданој садашњости у којој су куће разрушене а бунари затрпани.

Други светски рат, страдање српског живља, усташки злочини, етнички сукоби деведесетих јесу историјске, политичке и друштвене околности на чијој се позадини одиграва мозаична, анегдотска прича о широј породици поседнице тог наративног и аутобиографског ја: ту су дедови, тетке, ујне, баке који су искусили социјална и политичка превирања, њихове животне приче и њихови утицаји на формирање једне девојчице представљају веома важан фактор. Време прошлости и време приповедане садашњости које симболизују нараторкине различите тачке гледишта разликују се и графички: курзивом се одређује време садашњости, утисци, реакције и размишљања, накнадна мудрост али и накнадна чежња. Јунакињу видимо као спој два утицаја, завичаја и велеграда, као власницу два језика, једног стандардног и модерног, другог дијалекатског и архаичног, као особу решену да запамти што је више могуће детаља који чувају рајску димензију детињства и јамче да ће се простору одрастања и сећања стално враћати тако што ће га реконструисати у уму, машти и уметничком тексту. Аркадија као локалитет изгубљене среће али зато оствареног сазревања истовремено је и простор из снова и паралелна реалност у коју јесте могућ повремени повратак, али са којим ипак више нема потпуне идентификације. Изузев преко језика: језик постаје моћан покретач сећања и незаобилазна идентитетска разјасница.

Помажући се речима и сликама, јунакиња покушава да у сећању оживи митски простор одрастања и да га од идеализације спасе носталгичним сећањем. Начин на који супротставља садашњост и прошлост, историју и фантазију, потврђује сличност носталгије са меланхолијом: обе имају нејасне и универзалне, на класифика- 
ције несводиве узрочнике који измичу, само што меланхолија подразумева осећај личног губитка и онемогућености, док носталгија указује на везу са колективитетом, као и на везу интимног и колективног памћења, на могућност надомешћивања изгубљеног.

Описујући пределе у којима је одрасла, нараторка предочава и све оно што је изазивало неспокој и недоумице, а очекиван и подразумеван део тог одрастања је упознавање са Другим (културно различитим, номадским и егзотичним):

„Цигани - њих смо се плашили као деца (као и тенкова, када пролази војска на вежбу, негде у Папук). [...] Били су застрашујући, не онако романтичарски егзотични, како их опевају песници" (Гароња 2014: 281).

Деца живо и радознало из прикрајка посматрају чергу која шири шаторе на ливади и жене које се размиле уоколо да би гатале или испросиле нешто хране.

„Бака је примала оне које су знале гатати. Увек је проверавала сваку могућност да чује нешто о нашем деду, Николи, и давно после, а и о здрављу ближњих. И обично су јој говориле, наравно потврдно, да је наш деда жив, неђе у далекој земљи. Добијале су за то мерииу гра', мауна, лука, бундеву" (Гароња 2014: 282).

Размена дарова је уобичајено заснована на прећутној женској солидарности, узајамној утехи чији је важан чинилац храна. Пасуљ, „краљ свих ручкова”, је искључиво гра', он „брбла”, „ромори”, ври, „стварно прича - толико поетично и персонификовано!” (Гароња 2014: 157). Храна која говори је метафорично изникли текст из сећања, и сећање из текста.

Аутобиографска књига прозе Љубице Мркаљ Испричавалице дочарава рано детињство ауторке и доноси рекапитулацију и реактуализацију првих сећања и првих обликованих утисака о себи и свету. Овај низ кратких прозних целина уланчаних у фрагментарни роман говори о одрастању и сазревању будуће уметнице, о формирању њеног танкоћутног сензибилитета: приповедни субјект је поново у исти мах аутобиографско и наративно ја које треба да свету докаже своју индивидуалност и посебност, да савлада страхове и недоумице, да незнање преобрати у знање а несигурност у самопоуздање, да себе афирмише и дефинише у времену у ком су јасно видљиви трагови послератне немаштине, утицаји историје, политике, друштвених и културних конфликата и тензија. Играње различитих игара у том процесу представља истовремено пут интеграције и сазревања, али и опасност од изолованости и маргинализације. Кроз ритуале игре представљено је и како се девојчица постепено отвара за свет око себе, учећи кад у њему треба да буде невидљива и неприметна поред родитеља, сродника, ривала и пријатеља, доминантних брата и сестре, а када да себе стави у први план било проницљивим питањима и запажањима, било опростивим преступима и несташлуцима.

Историјско-идеолошки контекст Љубичиног одрастања више је сведен на дискретне наговештаје оних последица које на породични живот могу оставити опредмећене успомене и сећања у виду фотографија и привилегованих предмета - нарочито фотографија, „огледала која памте” (цитирано према Тодић 2015: 33), будући да су оне у оквирима модерног друштва несумњиво најважнији медијум саморепрезентације (Тодић 2015: 17). Дете које у кући налази успомене и фотографије тражи објашњење искустава рата, смрти или политичког прогона у претходним генера- 
цијама; објашњење се не тражи само зато да би задовољило радозналост него и зато што схвата да су то животне лекције које ће условити и његово одрастање.

Љубичин свет саздан је од тајни које се разоткривају страшћу, упорношћу и безграничном радозналошћу, делимично и од побуне против институција (иако је учитељица „мирисала некако цветно-млечно” а први дан школе препун „силине угушених узбуђења” (Мркаљ 2014: 50), исцртавање листова у свесци кружићима и цртицама не спада у узбудљиве задатке), а највеће тајанство биће везано за животе оца и деде, за њихова ратничка, махом неиспричана искуства, која до јунакиње стижу споро, у фрагментима које она мора сама сложити, најчешће принуђена да дуго и тврдоглаво, али истовремено и обазриво, испитује мајку. Колико је у њеном детињем поимању света тешко одвојити категорије природног од друштвеног сведочи и детаљ из дијалога мајке и тетке о одсутном течи белогардејцу: девојчица је чула речи „црвени не опраштају” (Мркаљ 2014: 138), и оне покрећу безброј асоцијација које ће мала Љубица одмах везати за природу која је окружује: „ко се кога плаши? Зелени белих или бели црвених? Ја сам тренутно била срећна што сам препознала белоушку и што мирно, без узвика, могу неко време посматрати узнемирени муљ[...]” (Мркаљ 2014: 138). Природа пулсира у ритму покрета животиња и људи; као таква, природа је и слика историје која ремети људски живот идеолошким поделама, бојама које нас разврставају на пожељне и непожељне.

Прозна целина „Лутка” тако ће открити вишеслојну причу о играчки која није играчка, већ амбивалентна породична реликвија. Симболика лутке у одрастању девојчице најчешће је недвосмислена: „жељени статус грађанке младе девојке ће демонстрирати на фотографијама позирајући са књигом у руци тек при крају 19. века, док ће лутка трајно остати пожељан атрибут добре девојчице” (Тодић 2015: 63). Међутим, ова родно кодирана играчка добиће у прози Љубице Мркаљ сасвим другачије значење. Лутка неће понудити прижељкивани друштвени узор женскости, већ ће покренути сећања на рат, на опасност, патњу и страх од смрти. О злослутној привилегованости ове играчке сведочи и податак да стоји на врху креденца „као заробљеница са зидина зачаране куле”, те да је одатле „зурила својим стакластим погледом у наш свет” (Мркаљ 2014: 11). У жељи да подели чаролију поседовања са другом децом, јунакиња ће их позвати да се играју, а та ће се игра претворити у препирку и битку у којој ће лутка бити покидана, да би уследило разоткривање трауматичне анегдоте из породичне историје. Лутка је, наиме, дошла у породични посед као део ненамерне ратне пљачке: извадили су је немачки војници из разбијеног излога и дали Љубичиној сестри, која се ту затекла са мајком. „Отето, проклето”, рећи ће мајка. „Нисам се усудила да то спречим, а потом, твоја сестра није хтела да се одвоји од лутке. Вукла ју је са собом кроз цели рат и све бежаније које смо преживели, бринући се, као да је та играчка неки живи створ. Није се ни играла с њом." (Мркаљ 2014: 26). Носталгију за миром и спокојним животом сестра је пројектовала на поклоњену лутку, као да је она била тајни извор моћи и заштите. Или се сестра можда само бринула о лутки онако како се њена мајка бринула о њој, на тај начин потврђујући да је разумела важност старања о другима?

Анегдота о лутки која преживи рат али не и дечју игру супротставља се причи о летећем тањиру, односно о једном сасвим обичном исликаном тањиру из ког се једе, а који је доспео међу породичне реликвије у време балканских ратова: тај 
је тањир, наиме, током једне жестоке битке пао пред ноге Љубициног деде, цео и неокрњен: „топови су грунули, скоро у исто време зачула се експлозија јер је кућа одлетела у ваздух, а пред нашег деду, на траву, слетео је један тањир" (Мркаљ 2014: 28). Док посматра фотографију „где је деда са дружином такорећи на сеоском сабору весело лешкарио на трави скоро ми намигујући из прошлости" (Мркаљ 2014: 27), не верује да је такав спокојан призор снимљен у ратно време али брат је уверава у супротно: „Јесте ратна, мада личи на неку забаву после обичне војне вежбе”, и додаје: „имамо и те какво сведочанство у витрини - један летећи тањир!” (Мркаљ 2014: 27). „Он га је понео за успомену са бојишта. [...] Мама га користи само у ретким приликама, као за славу, када на њега ставља славски колач.” (Мркаљ 2014: 28). То што се мушка херојска прича оконча на тањиру са славским колачем доказ је да се родна искуства преплићу на најчудноватије начине, и да су ратиште и дом често неодвојиве целине.

Рат је у прози Тање Ступар Трифуновић у дубокој позадини, не само због медитативног мапирања одрастања и сазревања као централног интереса њеног приповедања, не само због артикулације изазовне и тегобне везе невиности и искуства. Својим првим романом Сатови у мајчиној соби ова песникиња рођена у Задру а настањена у Бањалуци подржава ону струју наше женске књижевне традиције која негује интимистичку и исповедну комуникацију са узорима, значењима и знањима. Њен први и за сада једини роман чита се као историја женске депресије у контексту борбе против притиска околине, патријархалног кодекса и свега што спречава жену да ослободи своје друго ја, које је истовремено и фиктивни идентитет и читава миленијумска историја конфликта са мајчинском фигуром. На Тању Ступар као да је утицала Биљана Јовановић романом Пада Авала који је тему одрастања и сазревања прометнуо у побуну истовремено схваћену као дужност, у отпор систематским покушајима да се жена инфантилизује и маргинализује. Роман Сатови y мајчиној соби говори о борби три генерације жена да прихвате изазовно наслеђе матрилинеарности, а жанровска субверзија на којој почива враћа нас на поступак у роману Пада Авала: одрастање и сазревање у оба дела се дубински преиспитују јер нису природан и неспутан процес, већ мукотрпно ратовање против тенденција да се женски унутрашњи конфликти омаловаже. Роман Тање Ступар Трифуновић описује амбиваленције женско-женских односа на основу којих читалац схвата да пролажење кроз идентичне изазове сазревања међу женама ствара дистанцу и отуђење. Социјална интеграција јунакиње креће се танком линијом психолошке дезинтеграције, разобручавање њене свести подстицано је смењивањем приповедних гласова и синкопираним приповедним ритмом, дисконтинуитетом нарације и продуженим ефектом рефлексије која се претаче у дијалог са читавој женском историјом, са сродницама, наследницама и претходницама. Оба романа почивају на императиву потраге за идентитетом чији је покретач у роману Пада Авала генерацијски осећај осујећености, док је у роману Сатови у мајчиној соби потрага индивидуална и интимна, везана за кризу сећања која је универзална али никако апстрактна. Монолитној слици света у ком је жени припало да успоставља равнотежу између подмуклости и послушности с којим је суочена Јелена, јунакиња Биљане Јовановић, у роману Тање Ступар супротстављена је авантура градње и разградње флуидног идентитета. 
У архетипски заснованим симболима, везаним за природу, воду, плодове земље и морска пространства, отварају се сви профили и потенцијали женског сазревања: проговара се о сексуалности, мајчинству, брачној љубави, одвајању од родитељског дома и заснивању сопственог огњишта. Одрастање је процес грађења и разграђивања емотивних односа, али и потраге за срећом и усхићењем: „Дјеца у нама живе за ватромете. Бића у нама живе за своје сусрете. Све оно вријеме између тетурамо међу прашином и сјенкама, опијени сјећањем на ватромет” (Ступар Трифуновић 2014: 93). Љубав и детињство повезују слике несигурности. „У љубави сам љута дјевојчица која се преображава у збуњену дјевојчицу, тужну дјевојчицу, уплашену дјевојчицу и, најзад, срећну дјевојчицу која себи то тако ријетко допушта, јер сва та лица и све те дјевојчице које се разголићују пред тобом, то је страшно за мене." (Ступар Трифуновић 2014: 137). Роман Тање Ступар Трифуновић афирмише лирски сензибилитет који се грчевито бори да конфликти и парадокси женског одрастања буду релевантни и легитимни. Покретање теме матрилинеарности у контексту романа Сатови у мајчиној соби важно је добрим делом и због питања на који се начин формирају женско-женски односи, због разјашњења „енигме” о томе како дејствује женска генеалогија, због потраге за одговорима на низ недоумица и непознаница, попут оних као што су: да ли се женска обележја наслеђују или перпетуирају, остављају ли мајке кћерима наговештаје и упутства о томе како живети у свету, како се поставити пред патријархалним молбама и принудама, а како пред мушким миљем и насиљем и, коначно, како макар окрњити врх леденог брега дуготрајног ћутања о свему што се женским зове, па макар било одсутно, расуто и скривено.

У прози Јелене Ленголд теме сексуалности, емотивне блискости, усамљености и страха од смрти отелотворују се изван оквира реконструкције сећања: ова ауторка опседнута је проблематизовањем границе између доживљеног и измаштаног. Њен свет не познаје историјске ни друштвене турбуленције, замрзнут је у туробним валерима неизвесне и напете потраге за срећом, страшћу и спокојем. Већ прича „Узроци”, прва по реду у првој прозној књизи ауторке која је књижевну каријеру отпочела као песникиња, говори о томе како не постоје самоникла срећа и блаженство, већ је све условљено поштовањем ванвременских ритуала који су за емотивни спокој јунака нужни, колико год били ирационални. У овом случају, ради се о ритуалу као виду осигуравања брачне среће: супружници приређују обилну вечеру за пријатеље, следећи урбанизовани архетипски императив. „Заклаћемо метафоричку овцу”, каже супруг; тај ритуал покреће жеља да се сачувају од деструктивног утицаја мартовских ида, „дана пуног месеца” који су „светковина бога Јупитера”. Јупитер је муж Јуноне, богиње Месеца, напомиње нараторка, а у дане ида, „Римљани би му приносили заклану овцу на жртву” (Ленголд 1994: 9): стога ће брачни пар врховног паганског бога умилостивити вечером у знаку „великог, округлог, сјајног и потпуног Месеца" (Ленголд 1994: 9). Прича је испуњена тескобом и стрепњом, помешаним осећањима жеље да се тренутна срећа и хармонија сачувају заувек, и страха да би све лепо могло пребрзо нестати. Као што Шекспиров Тимон Атињанин гозбама за пријатеље обезбеђује њихову, испоставиће се несталну, љубав и дивљење, јунаци приче „Узроци” вечну срећу желе да обезбеде калкулантским, тренутним усрећавањем других. Опсесивно-компулзивно понашање, неспокој и слутње поништавају срећан и миран крај. У срцима брачних другова никада неће бити вере у трајност љубави и среће, о чему сведоче не само узнемирене птице, него и магла над реком. 
Мрак онеспокојава, али ни светлост дана не доноси смирење, јер чак и сјај сунца јасно показује све оно што би јунаци желели да сакрију или игноришу.

У причи „Прозори” јунакиња (која је истовремено и нараторка) опседнута је сновима и смрћу, што се показује упоредним представљањем детињства и зрелог доба, с циљем да се покаже како ни до какве суштинске промене не долази са одрастањем, јер страхови и неспокој су неискорењиви; као дете, јунакиња измишља приче о опасностима и породичним трагедијама (другарици прича измишљену причу о сестри близнакињи коју је прегазио камион), сања снове у којима је напуштена и беспомоћна, што све наговештава депресију и несигурност у зрелом добу. У тренуцима брачне среће јунакиња само размишља о томе како ће се она и муж једном растати, или како ће се неко од њих двоје разболети па умрети. Њено жаљење због пролазности срећан и складан брак само је учинио конкретнијим: управо брачна срећа фокусира жаљење на пролазност, будући да јунакиња, како каже, зна да „срећа може постојати само негде где су појаве вечне” (Ленголд 1999: 29).

У за сада једином објављеном роману Јелене Ленголд Балтимор главна тема је писање, настојање јунакиње да напише роман, да споји свет чежње и маште са својим реалним, једноличним животом, да укрсти креативни процес са психотерапијом. Док исповест тече као селективно сећање на привилеговане тренутке радости и криза, терапија се одвија као низ сусрета са сновима, психотестовима, цртежима - једном речју, психотерапија је низ индукованих реакција и асоцијација, сажетак и имитација живота, управо оно што ће се преточити у књижевни текст. Блискост са читаоцем успоставља се кроз исповест - јунакиња без имена говори о својој породичној историји од успомена из детињства до трауматичних односа са мајком и амбивалентне блискости са мужем; исповест је део терапије, као што је и покретач терапије исповест. Трауме, страхови, сагрешења и тајне се из казивања читаоцу претачу у казивање психотерапеуту, али са више елемената симболичног и театралног. У психотерапијским сеансама јунакиња је суочена са другом женом, која је и лекар и супарница; терапеуткиња је и исцелитељка и оличење сваке непријатељске фигуре из емотивне историје главне јунакиње. Окосница Балтимора је писање као формативни чин претварања доживљеног, жељеног и маштаног у уметнички текст.

Писање књижевног дела се у стратегијама женског ауторства неретко скрива и маскира у нешто што не одражава тачно и егзактно сам ауторски процес: уметнички поступак маскира се у исповест, у привид интимности, у контемплацију и сећање. Обазриво и ненаметљиво а истовремено потресно и провокативно, анализирају се слике из живота жена и девојака, истражују тегобне теме старости и смрти, одрастања и сазревања, приповеда се о тугама и љубавима јунакиња и јунака, о зближавањима и разумевању, о неизлечивој усамљености у окружењу које је неретко преоптерећено историјом. Гротескност инерције и аутоматизма у људској егзистенцији једна је од честих тема које се супротстављају преосетљивости јунакиња и нараторки, које не успевају да достигну живот као идеалну равнотежу жељеног и оствареног. Ипак, стање кризе, потраге, преиспитивања и борбе за склад воде, ако не идеалном свету онда бар заводољавајућој егзистенцији која је далеко од принудних ограничења и неприродних подстицаја о којима је, не тако давно, говорио Џон Стјуарт Мил. 


\section{Литература}

Гароња С. Повратак у Аркадију. Београд: Српска књижевна задруга, 2014.

Ленголд Ј. Покисли лавови. Београд: Српска књижевна задруга, 1994.

Мркаљ Љ. Испричавалище. Београд: Српска књижевна задруга, 2014.

Ступар Трифуновић Т. Сатови у мајчиној соби. Источно Сарајево: Завод за уџбенике и наставна средства, 2014.

Тодић М. Модерно дете и детињство: модели фотографске репрезентаиије детеma. Београд: Службени гласник, 2015.

Lengold J. Lift. Beograd: Stubovi kulture, 1999.

Mil Dž. S. „Potčinjenost žene.” Džon Stjuart Mil, Herijeta Tejlor Mil. Rasprave o jednakosti polova. Preveo Ranko Mastilović. Beograd: Filip Višnjić, 1995.

Stoller R. Sex and Gender.

Vladislava S. Gordić Petković

THE IMPORTANCE OF GENDER-SPECIFIC EXPERIENCE IN CONTEMPORARY SERBIAN FICTION

Summary

The subject matter of women's experience turns into a confusing issue due to a lack of bold and resolute critical reconsideration of the plots dealing with female growth and development. The paper sets out to explore the perspectives and strategies of transposing gender-specific existence in contemporary Serbian fiction and to illustrate radical changes in the concept of reality and writers' concern with the fidelity to women's experience. The fictional realism of the contemporary age will also commit itself to young or middle-aged individuals that passionately struggle to define their aims and objectives so that they could fit into a newly constructed and acquired concept of reality.

Jelena Lengold, Ljubica Mrkalj, Slavica Garonja and Tanja Stupar Trifunović use various symbols in their search for meaning within a repetitive paradigm of dreams, obsessions and traumas: their coming-of-age narratives deal with both the invention of solitude and the fear of happiness which at times becomes as unbearable as the fear of death, while the intense awareness of love's fragility and inability to promise eternity stems from the turbulent political and family histories. The narratives analysed in the paper focus upon the concept of growing up, the idea of winning an everlasting love and coping with its numerous triumphs and tribulations.

The novels and stories analysed in the paper demonstrate show that the distinction between the world of memory and the real world narrows, as the narratives range from intimate confession in letters and journals to the accounts of dreams and fantasies introducing verbal and structural experimental practices which involve shifting points of view. The literary transformation of women's experience has to cope with antagonistic and ambivalent attitudes towards the tradition and the practices of gynocriticism, since the mediation of women's experience calls for the fundamental reconstruction of those epistemological and interpretative norms and practices related to the making of a literary work. Afraid that her unique experience might be transformed into a cliché, a woman author is always asking the question of relevance - is the experience of a woman's growing up and reaching maturity important enough to be fictionalized?

Key-words: novel, growing up, women's experience, poetics, experience, autofiction. 